$J J M L L$

\title{
Women of War in Paul Auster's Man in the Dark
}

\author{
Mojgan Abshavi \\ Department of English Language and Literatures, Payame Noor University, Iran \\ Mohammad-Javad Haj'jari* \\ Department of English Language and Literatures, Razi University, Kermanshah, Iran
}

Received on: 17-8-2020

Accepted on: 17-12-2020

\begin{abstract}
Auster's Man in the Dark includes numerous war stories that altogether contribute to its overall message about the different shape of the world if there were no wars. Most of these war stories are about the miscellaneous effective roles of women during wartime and its aftermath; their contributions to the progress of wars; their victimization as wives and captives; their sufferings as widows and laborers; and their drastic change of identity in accepting new social roles traditionally unachievable. These images of women of war make Man in the Dark a novel about women, although it literally seems not to offer any points about them. This paper is thus to argue that Auster seems to be presenting himself as a pro-feminist in this novel, which is basically about war and what causes war, in highlighting women's roles during wartime and how their contributions have been unfairly silenced.
\end{abstract}

Keywords: Auster, Man in the Dark, war, women.

\section{Introduction}

Women have inevitably played different roles during wartime in any part of the world. They have played soldiers and resisters fighting on front lines: mothers inspiring their soldier-sons, nurses treating the injured, wives and widows economically substituting their absent or deceased husbands in factories and on farms, workers helping with the production of munitions and war stuff, double agents going on missions for their countries, showgirls entertaining and encouraging their soldiers, wives and mothers looking after their injured men after the war, and, unfortunately, victims to be tortured, raped, and slaughtered. Besides, according to L. Weatherford, roles undertaken by women during wartime, especially $20^{\text {th }}$-centuey wars, were unprecedented: women officers, army nurses, wartime congress women, female war artists, female war historians, female war correspondents, female spies, as well as female labor force in aircraft, shipbuilding, munitions, and the electronics industry (2010, xii). However, there exist dark roles that women of war went through, contrary to their victimization in former times: "images of teenage women who smile while abusing prisoners at Abu Ghraib" (Oliver 2007, 20) - one can add all the Jihadi women who attended ISIS and similar terrorist groups.

() 2021 JJMLL Publishers/Yarmouk University. All Rights Reserved,

${ }^{*}$ Doi: https://doi.org/ 10.47012/jjmll.13.4.9

* Corresponding Author: hajjari.mohammad@razi.ac.ir 
Abshavi, Haj'jari

The problem with women and their contributions to the phenomenon of war is in fact the paradox of their absence amidst their presence. In other words, females have been, as L. Westerfield puts it, mostly denied "a literal as well as a figurative presence on the battlefield" throughout history. Socio-cultural prohibitions have mostly prevented them from attending wars and military-based conflicts, and the burden of such subjugation has "silenced" them to be effective "narrators of war and resistance" (2010, 20). The very statistics of wars throughout history literally point to two categories of casualties - militants and civilians (mostly women and children) - while female militants have always been there, jailed, injured and/or killed. It might be only through the explosion of data in modern times and demarginalization of women on all grounds that old and new statistics about women of war have revealed themselves.

On parallel lines with the socio-political issues about women moves the "virtual absence of women authors from the canon of war literature" (Westerfield 2010, 20), a fact confirming that women have been rather unfairly ignored as commentators/reporters/narrators whenever the subject of war has been concerned. The definition of womanhood, in its traditional sense, has always been the touchstone to perceive women and ascribe fixed roles to them throughout history as too weak in power to even defend themselves throughout wars. Reviewing war accounts, ironically blissful commands by war lords, such as 'kill all but women and children', are arresting enough. P. Goodman argues that "Women's narratives, their descriptions and interpretation of the experience of the war years, offer vignettes that expose the gendered nature of wartime social relations" $(2002,5)$. Sharing wartime experience, reporting war from memories, and commenting on war by women are essentially important because many people are still ignorant of women's contributions to wars. The memories from these experiences "present a medium through which to explore important aspects of social life and social relations in transition" (Goodman 2002, 5). As J. Giles suggests, such testimony can show when "ideologies were resisted" and when “silence became significant as articulation" $(1992,245)$. Although conscious silence at times is a pious act of reticence and sometimes articulation is blocked by the ineffable, enforced silence is to keep someone altogether out of the discussion. "It is silence, indeed," Weatherford says, "as well as a lack of big-picture thinking, that causes the exclusion of women in historic narratives, not malice-and certainly not a lack of material" (2010, xi). However, “women's resistance literature" has generally the potential to argue for "war and resistance" and lead readers to a better understanding of women's actual contributions to resistance movements (Westerfield 2010, 8). War, generally affecting all, has its own subjective interpretation by every single soul, hence the gender-particular perception of war.

As a common theme in literature, war is the subject of many epics, romances, novels, poems, and plays. The question here is to what extent these writings have highlighted women's roles and sufferings during wartime, regardless of men's contributions. The portrayal of women during wartime is not specifically highlighted before the $20^{\text {th }}$-century literature, and one has to point to "the relatively few women authors whose poems, short stories, or novels have been accepted into the canon" of war literature about women (Westerfield 2010, 21). Studies such as Plain's Women's Fiction of the Second World War: Gender, Power and Resistance (1996) or Hartley's Millions Like Us: British Women's Fiction of the Second World War (1997) have introduced British women's writing of WWII. Certain novels like West's 
The Return of the Soldier (1918), Woolf's Mrs. Dalloway (1925) and To the Lighthouse (1927), Hemingway's A Farewell to Arms (1929), Mitchel's Gone with the Wind (1936), Hannah's The Nightingale (1939), Huth's The Land Girls (1995), Quinn's Half of the Human Race (2011), and Messineo's The Fire by Night (2017), among others, contribute to the subject of women of war. In this light,

As women's resistance texts demonstrate, no one can avoid the effects of war as they ripple out over a society. This literature has the power to restore some of the fundamental elements - the moral uncertainties, the conflicting emotions, the value of home life and of human relationships amidst chaos and violence-that have been bleached from today's sterile vocabulary of war. (Westerfield 2010, 9)

In the same vein, M. Higonnet and P. Higonnet hold that while female authors lack the direct "battlefield experience" to legitimate their narratives of war, they are still willing to cry out their opinions about the biased relations between men and women during wartime (1987, 31). Although it is true that "women's silence and absence then and now reveal the masculine nature of narratives of war" and that "male experience has been prioritised at the expense of female knowledge" (Goodman 2002, 6), it cannot be said that male writers have essentially degraded women in their war stories. Many writers with feminist, anti-feminist, or pro-feminist attitudes have more or less depicted issues about women of war in their stories, whether they have tried to highlight women's roles or not. Many examples can be found in literature written by men, although women might not have occupied the core of their writings and their heroism might have been kept silent.

Among such writings, certain types of fiction in the postmodern era use techniques either to present women in traditionally masculine roles or represent women in those roles with new highlights to attract attention to their unique contributions. Paul Auster provides us with such techniques through his or others' fair representations of women. When his own perspective is concerned, Auster can be argued to speak for women either through realistic portrayals of mutual respect between males and females or postmodernist accounts of humankind in general, gender excluded. And when his re-presentation of others' representation of women is concerned, he might be illuminating the simulacra at work to define the roles of women through an endless chain of signifiers entrapped within a plethora of spatio-temporal settings, either historical or virtual. In this regard, reading Paul Auster's Man in the Dark (2008), henceforward $M D$, serves to highlight the roles and situation of women during different war settings, recounted through historical and multimedia data, the later basically serving as simulacra.

Since $M D$ is seemingly concerned with male protagonists, reading to highlight the significant position of women during wartime is intriguing. Auster seems to argue that, when war strikes, men and women both play significant roles in its progress. Thus, he argues in a letter to J. Coetzee on March 8, 2011:

What we are told in the American press is that spontaneous revolutions have occurred in Tunisia and Egypt, that protest movements have sprung up in several other countries throughout the region, and that the conflict in Libya is quickly 
Abshavi, Haj'jari

devolving into a bloody civil war. To concentrate on Egypt for the moment: it seems that the peaceful uprising was secular in nature, for the most part led by young people in their twenties and thirties-educated young people who are largely unemployed or underemployed because of the malfunctioning society created by years of corruption and dictatorship - and supported by women, civil servants, impoverished workers, and even the military. $(2014,217)$

Auster does highlight women's roles during all revolutions and uprisings, no matter their working class and profession, and he is not arguing against them. $M D$ likewise includes a myriad of war accounts, mostly about women, each somehow concluded so that the narrator August Brill can escape the memory of his late wife and his granddaughter's boyfriend, the former a victim of cancer and the latter a victim of war. We are thus presented with the story of Virginia, who is a double agent during wartime; the story of a pretty young woman who was imprisoned and quartered in a Nazi camp during WWII; the story of a teenage girl who sat for two hours in a park so that she could be secretly ogled by an SS officer who then gave her and her family exit visas; the story of a woman who suffered the absence of her double-agent husband for fifteen years during the Cold War; and the story of Katya whose boyfriend Titus was cruelly beheaded in the Iraq War. August and his granddaughter Katya also watch and comment on four movies in which women play central roles. Three of them are directly concerned with war and women: the story of a widow in Tokyo Story whose husband went missing in The Pacific War; the story of a German woman in La Grande Illusion who lost her husband and three brothers in WWI but generously lets two running French prisoners-of-war into her house; and the story of an Italian woman in Bicycle Thieves who sells her bed linens to help her husband buy a bicycle for his job in the post-WWII atmosphere of unemployment in Rome. As August tells Katya, these movies are "all about women. How women are the ones who carry the world. They take care of the real business while their hapless men stumble around making a hash of things. Or else just lie around doing nothing" (Auster 2008, 21). Interpreting $M D$ as such presents readers with a deeper insight into one of Auster's messages in the novel, that of the active roles of women during wartime.

Auster's pro-feministic attitudes in $M D$, in which the protagonists are men, might not seem overt enough regarding his complex stand on women in his oeuvre. As we read into his autobiographical writings in The Invention of Solitude, Hand to Mouth, and Winter Journal, Auster has been a nice family guy, being in good terms with his mother and sister, now adoring his famous wife and daughter. He was even in a good relationship with his ex-wife, with whom he fell out not on a personally motivated basis. Besides, reading into one of Auster's letters to Coetzee, he is proud of men, including himself, who have the blessing of "long marriages to remarkable women;" and that he "would be disappointed" if he learned that such men were cheating on their wives and had young mistresses "stashed away in an apartment somewhere" $(2014,5)$. In the same letter, Auster expresses his belief in equal rights in marriage between men and women: "Marriage is above all a conversation, and if husband and wife do not figure out a way to become friends, the marriage has little chance of surviving" (8). Regarding Auster's portraits of ladies in this context, to mention a few examples, we can begin with In the Country of Last Things, henceforward CLT, in which women have central roles in managing communal life in a wasteland. In 


\section{Women of War in Paul Auster's Man in the Dark}

Leviathan, Auster's network of relationships among men and women is too complicated to give any priority of thought and action to either sex. In Mr. Vertigo, one woman on the margin plays a central role, in a positive way, in the life of the two male protagonists. In The Brooklyn Follies, women are given full authority to cultivate their femininity. Besides, Nathan as Auster' male protagonist criticizes pornography, male dominance, and his own impotency to be a good husband and father. And in $M D$, excluding other novels for the sake of brevity, women are given central roles on both domestic and social levels. However, studies exploring Auster's feminism, in light of popular feminists' theories, have been essentially submerged by research into more evident ideas, discussed below, in his writings. However, it cannot be denied that Auster has his support of women's cause in between his other courses of thought.

\section{Review of Literature}

No research has been done so far on the portrait of women of war in Auster's MD. According to M. Brown, "Gender does not figure significantly in Auster's work as a theme" (2007, 156n6). However, Auster somehow acknowledges I. Siegumfeldt's comment that "Women become rounder and more prominent" in his later work (Auster and Siegumfeldt 2017, 117). Likewise, S. Ciocia argues that scholarly discussion of Auster's work has not basically concentrated on his representation of women, being sacrificed to such "recurrent topics" as existentialism, postmodernist techniques, identity crisis, and language games in interpreting Auster's fiction (2011, 97). However, in P. Alina-Oana's view, we can learn from August Brill's narrative in $M D$ that "we can define ourselves by the fictions we create and by the stories we tell about ourselves." These stories can be "beneficial, providing a strong sense of identity, or tremendously destructive, like personal, national or global tragedies" $(2014,217)$. In this regard, one can find links between the characters across the diegetic levels in $M D$, including the female characters during wartime or its aftermath, to find similar experiences between them.

\section{Discussion}

In his fiction, Auster argues about war only in retrospective when his characters talk about the World Wars, the Vietnam War, the Iraq War, 9/11, and some other conflicts. However, concerning women, one can find traces of his concerns with women during wartime specifically in CLT and MD. Auster's direct concern with war and women appears in CLT, a dystopian novel about the adventures of a woman in a war-stricken city. Anna Blume, Auster's only female protagonist throughout his writings, is presented in this novel as a strong and willful woman who, while looking for her brother, tries to help others against their problems as well. she finally settles in a place, Woburn House, which is run by a woman and her assistants who help refugees with shelter and food. Regarding $M D$, the concern here is not to say that the novel is specifically about war and women. Contrary to the title of this novel, we see Auster defending women's cause during and after wars by recounting a selection of war events that happened to certain women, mainly narrated by a man concerned with the memories of his deceased wife and the suffering of his betrayed daughter and war-stricken granddaughter. It should also be noted that the male narrative voice of the man in the dark, tortured by insomnia, speculating about life through what if's, does not give precedence to a manly interpretation of war and that the intricate accounts about women objectively 
Abshavi, Haj'jari

portrayed in the context of war neutralizes any specific male ideology against women. Added to that are the memories of his late wife, thinking about his daughter's and granddaughter's problems, accounts of women of war, and the different images of womanhood on the screen. In this light, $M D$ can be discussed regarding its portrayal of women during wartime and their share of whatever happened during and after wars, specifically WWII.

In the case of women of war, "certain images characterising Second World War women have entered into popular culture and discourse" (Goodman 2002, 6). These images, now being established after seven decades ever since, give us a compact categorization including female war victims, the woman of resistance or "the resistance fighter," "Rosie the Riveter" or the female worker during war, the "Homefront woman" or "the long suffering housewife and mother," and "the girlfriend" awaiting her man at war (Sheridan 1990, 36-37). Most of the war accounts by Auster in $M D$ are about such portraits of women, accounts given through either historical or multimedia approaches.

\subsection{Women of Resistance: Double Agents and Female Resistance Groups}

The "wartime heroine," as D. Sheridan points out, is an everlasting figure developed from the genre of "the lady detective, the secret service agent or double agent," who can be found in "spy stories and thrillers." Modeled on resistance fighters in the real world, she can be either "pure and heroic" or "threatening and dangerously sexual" $(1990,36)$. Once can find an accessible depiction of such women in James Bond's movies, women whose roles as foils in Bond's service or femme fatales against him are revealing enough during the Cold War. In the context of WWII, the 'wartime heroine' might come from any country involved in the war, mainly from England, France or Russia due to their professional secret services. She may be equipped with weapons, as a modern depiction of female fighters carrying bows and swords in old times. She may work alone as a secret agent or work collaboratively in gangs, cells, clubs, and groups, or fight in troops run by either male or female commanders. Regarding the scope of her activities in this light, a 'war heroine' thus mixes female qualities like "beauty compassion, resourcefulness and a certain vulnerability" and male qualities like "ruthlessness, courage, endurance and the ability to kill" (Sheridan 1990, 36). Accordingly, even a seemingly fair definition of a war woman in modern times still lies in contrast to the definition of a war man, highlighting the old binary opposition, while women of war have had their unique contribution to humanity in general in so far as the survival of the community through both the sexes is concerned.

Auster's earliest image of a resistance woman is Anna Blume in CLT whose "resistance and selfpreservation" in a post-war dystopian city is admired by Auster (Martin 2008, 156). Regarding MD, Auster presents us with two "wartime heroines" in the sense of what Sheridan says: the waitress Molly Wald and the agent Virginia Blair. Molly Wald, who initially seems to be a simple waitress allowing Owen Brick to stay in her apartment, is in fact an agent's girlfriend who works for Lou Frisk, a higherrank agent. Molly's real identity is revealed when her boyfriend, Duke, turns out to be Frisk's man and deadly beats Owen when he wants to escape their apartment. On the other hand, Virginia later reveals to Owen that she is a double agent actually working for August. When Molly and Virginia are initially presented to us, they do not raise suspicions; they are beautiful, compassionate in giving Owen shelter - 


\section{Women of War in Paul Auster's Man in the Dark}

Virginia even makes love to him - and they are resourceful in perfectly doing their jobs. However, they are equipped with manly qualities in being ruthless against their enemies in wartime, courageous as members of resistance groups, and fearless to kill. Virginia's role is even more colorful than Molly's as she shows more courage and resourcefulness as a resistance woman. She has even lost her husband at the beginning of the civil war and has been trying to avenge him since then. Auster's playing with roles that women can play during wars or similar conflicts, in the 21th-century setting of $M D$, actually draws from similar cases during WWII. Virginia's and Molly's cases thus refer to the older ones like that of the French resistance woman Marie-Madeleine Fourcade, who survived WWII for the French front (Whaley 2006, 192), and the spy roles women played during the Cold War.

Another example in $M D$ about women of resistance is about a captive of concentration camps. Once in Brussels with his wife, August had the chance of visiting her second cousin, Jean-Luc, who took them to a small courtyard to show them "a bronze statue of a water nymph sitting in the pool" (Auster 2008, 119). Jean-Luc reveals that the model for the statue was his high school literature teacher who was only seventeen when she posed for the artist. On the German occupation of Belgium in 1940, the 15-year-old Jean-Luc joined "an underground resistance cell as a courier, attending school by day and running messages at night." His teacher joined the resistance as well, but she was arrested in 1942. When the war ended, he learned that she had died in a concentration camp, executed in public "to set an example for the other prisoners and demonstrate what happens to people who disobey the guards." She had been "drawn and quartered" by four jeeps pointing in four different directions (121). This episode, even if fictional, is not far away from the events at Auschwitz and concentration camps during WWII. A case in point is Klaus Barbie, an SS and Gestapo functionary, who tortured many French Resistance members to death during that war. Known as the "Butcher of Lyon" (Diehl 2007), Barbie was responsible for the death of many people back then. The women who survived his tortures recall disgusting memories: they were hit in the face; they nearly drowned in a bathtub - "the bathtub torture;" their vertebrae were broken; their teeth were broken; their hair was pulled; a bottle was put in their mouth so that their lips would split in two; and they were hung up by hand cuffs with spikes inside them and were beaten with a rubber. All the tortured women "depicted Barbie as a harsh, sadistic officer ready to resort to any cruelty to extract information." "Have you heard of the Gestapo kitchens?" Barbie used to say when he referred to torture chambers ("Klaus Barbie" 1987). Auster's account of Auschwitz in this regard might of course serve his Judaism as well, although his main concern here is how cruel the concentration hells were for women regarding the sexual harassments involved in their tortures, issues that are kept silent in his account. In "women's resistance narratives," as Westerfield says, it is possible to observe the impact of Nazi ideologies on women's lives and "how women, customarily excluded from politics, resistance, and combat, ultimately chose to respond to the inhumanity of these dictatorships" $(2010,9)$. The topic of "anti-Nazi activity by women" has recently attracted the attention of historians, and "literary treatments of the topic have rarely made their way into critical discussion" (8). While women might have remained silent only to speak at law courts against war crimes against them, as in Barbie's trial, literature has never been silent; any fictional portrayal might originate from a real event. Jean-Luc's account in $M D$ is 
Abshavi, Haj' jari

fictional but torture of women and men did happen in concentration camps, especially against resistance groups. Besides, while Auster has limited himself to a certain plot line regarding female resistance groups in WWII, it can be argued that his account serves as a synecdoche to refer to other cases in which women were involved in activities such as providing Jews and political refugees with safe houses, transmitting secret messages between resistance groups, and running escape lines for children and refugees.

\subsection{Female Workers during and after Wars}

It is naturally true that when men, as the main labor force, are missing, women are the only substitutes to replace them, especially at wartime. This fact generated new identities for women on the outbreak of WWII. According to Sheridan, during WWII, "the poster of a healthy, strong woman (Rosie the Riveter) in turban and dungarees, flexing her biceps, graced the hoardings of American towns and was used to encourage women to volunteer for war work." Similar images were used for the same objective in Britain. As a consequence, "factory workers and girls in dungarees" filled the pages of popular magazines in Britain. After the war, this portrayal of female potency was stored, merely to "reappear in post-1970s feminist culture as a positive image of women doing men's jobs." Rosie the Riveter also appeared on postcards in 1985 along with pictures of "women driving tractors, welding tanks, repairing ships, climbing scaffolding." The most significant contribution to this culture was the American documentary "Rosie the Riveter" in which women talked about their wartime experiences as labor force (1990, 36). Such "woman in uniform," as Sheridan calls them (38), sometimes took completely new jobs to replace the men who joined the war or the military. "Rosie the Riveter" is thus used as a symbol of "American feminism" and "women's economic advantage" (Duncan et al. 2008, 268), a culture that spread throughout Europe as well.

Female workers, as the new type of identity for women of war, were not restricted to war years. Even postwar years witnessed the contribution of women to the economy of the family and the country. Auster's case in point in $M D$ is women's profile in the movie Bicycle Thieves (1948). As August says, discussing the beginning of the movie,

The hero is given a job, but he won't be able to take it unless he gets his bicycle out of hock. He goes home feeling sorry for himself. And there's his wife outside their building, lugging two heavy buckets of water. All their poverty, all the struggles of this woman and her family are contained in those buckets. The husband is so wrapped up in his own troubles, he doesn't bother to help her until they're halfway to the door. And even then, he only takes one of the buckets, leaving her to carry the other.... the wife comes up with the idea to pawn their bed linens so they can redeem the bicycle. (Auster 2008, 16)

Bicycle Thieves is the story of an Italian family who struggle for living just like other lower middleclass families in post-WWII Rome. When the protagonist is to buy a bicycle for his new job, it is his wife who willingly sells her white bed linens, the symbols of their marriage, to financially help him. In August's words, this movie along with the other ones he talks about are "all about women. How women are the ones who carry the world. They take care of the real business while their hapless men stumble 


\section{Women of War in Paul Auster's Man in the Dark}

around making a hash of things" (Auster 2008, 21). He continues that the husband "doesn't notice how hard it is for his wife to carry those water buckets" (22), suggesting that he seems to be forgetting his wife's contribution to the welfare of the family in postwar years. Even after buying the bicycle and receiving his outfit, he mockingly tells his wife that "There's a job for you too. You have to tighten the strap on my cap. It's loose," at which she merely laughs (Bicycle Thieves 1948, 00:10:06-00:10:12). Although he thinks that his wife is actually doing something easier than his job, we know that she is doing her best at home to treat their infant and do the chores before poverty. She is the representative of all those women who suffered likewise but worked hard to support their jobless husbands after the war. There are a number of women at the beginning of the movie fetching water from a well, the wife being among them, and they are rather indistinguishable from each other in their similar dress which can recall how stereotypical roles they were still supposed to play in the household. Finally, when the husband locates the thief of his bicycle, the thief's younger sister appears with several match boxes she might have been selling outside (01:18:00-01:18:10). It is not hard to imagine the situational irony here: the cohabitation of a stealing man and a hardworking woman living under the same ceiling and the contrast highlighting their different understanding of life under harsh conditions.

On similar grounds, there is a scene in La Grand Illusion (1937) that suggests how women's outfits and hairstyles changed due to war. The scene shows men trying women stuff for a show at the camp, one of them saying that "Women's skirts are short now, just below the knee" (00:28:14), and that women "wear their hair short too" (00:29:40). During WWI, due to the necessity of working for women to substitute their men, women's clothes actually changed for effectiveness at work, a phenomenon which consequently gave rise to more social freedom for them. However, the sexual undertone of the man's speech degrades the hardships women had to tolerate, both physically and emotionally, to replace their men within those outfits in favor of the satisfaction of the male gaze.

\subsection{Women as War Victims: Housewives, Mothers, Girlfriends, Sexual Objects}

Women as war victims can be generally argued to include those who lose their men in wartime; those whose men are held as prisoners of war; those who become prisoners of war themselves, tortured or sexually harassed afterwards; and the widows in postwar years who have to handle economic problems and psychological turmoil on their own. There are many real accounts of such women who are still

suffering from the loss of their men, tortures, and trauma among which Auster presents us with a couple of accounts in $M D$, all being powerful enough to make readers feel strongly sentimental.

The first story comes from Alec Foyle, a British journalist who dined with August and his wife while they were in Paris. His story is about a woman who was born in a Jewish family in Berlin in the early 1920s. When the Nazis took power in 1933, her family "reacted in the same way so many others did: they believed that Hitler was nothing more than a passing upstart and made no effort to leave Germany." However, when she was seventeen or eighteen, her parents received a letter from an SS captain who had expressed his love for her. Because Jews were in danger, and since he was unable to propose marriage due to the war, he could help them escape the country under one condition: 
Abshavi, Haj'jari

next Wednesday, at ten o'clock in the morning, your daughter will go to the park across the street from your house, sit down on her favorite bench, and stay there for two hours. I promise not to touch her, not to approach her, not to address a single word to her. I will remain hidden for the full two hours. (Auster 2008, 122-123)

The girl did it, "even though the family feared it was a hoax, not to mention the direr possibilities of molestation, abduction, and rape" (124). The following day, "the exit visas were slipped under the door as promised, and the family left for England" (125). The SS captain might have fallen for with the girl, and what he did was both for his love and her safety. However, the voyeurism suggested by this episode is another kind of abuse which objectifies the womankind. This case can refer to many cases in which women were subject to harassment during wartime. Auster gives us no hint to reveal the SS captain's true love or lust, but the very aspect of harassment is an inevitable fact of war. As Goodman says,

As the war progressed, many women struggled to achieve self-determination and shake off definitions of femininity imposed on them by men. As actors they subverted and occupied male spaces contradicting alternative constructions of femininity. Nevertheless, the dominant heterosexual feminine image was secured through an increase in the visual representation of women in erotic cartoons or 'pinup' photographs. $(2002,110)$

War rhetoric suggested that there was a "representation of what would seem to be a political threat as if it were a sexual threat" (Higonnet and Higonnet 1987, 37). There are a bunch of posters of showgirls pinned on the walls of all the camps of prisoners-of-war in La Grand Illusion, a fact that adds to the roles that women played during the World Wars to cheer up soldiers and covertly satisfy their erotic fantasies. Goodman argues that "There was a connection between the power and the control of the images" in this regard $(2002,111)$. Costello believes that the pin-ups "probably served less for individual enjoyment than as occasions for the social affirmation of virility" $(1985,192)$, since war and masculine virility were tied to each other. The "conflation of the female sex symbol as a male morale booster and bonding agent" was epitomized by certain theatres such as the Windmill Theatre in London in which "female nude shows provided continuous entertainment for soldiers and civilians alike" (Goodman 2002, 112). Indeed, during the blitz "its showgirls became symbols of courage as well as of sex" (Briggs 1975, 211). In La Grand Illusion, even a show is performed in one of the camps in which, because there are no women players, younger male soldiers with better-shaved bodies wear women clothes to play certain female roles. Recalling young actors' cross-dressing during the Renaissance, these shows are demeaning for both sexes. In this manner, women are still imagined as objects of erotic satisfaction, their clothes being fetishized to replace them. And younger soldiers are deprived of their potential virility by wearing women's dress. Moreover, images of homosexual tendencies are implied from the scene in so far as more virile soldiers might approach to touch the younger ones dressed like women.

The next story August remembers is that of a Parisian cellist, Françoise Duclos. Françoise "married her husband in the mid-sixties, gave birth to a daughter in the early seventies, and two years after that the husband vanished." Françoise knew that her husband loved his family and thus his absence looked suspicious (Auster 2008, 125). He was "declared legally dead" after fifteen years, and Françoise never let 


\section{Women of War in Paul Auster's Man in the Dark}

any man into her life again. She raised their daughter with the help of her parents, was hired by the orchestra, and gave private violin lessons, living "a pared-down existence" with "an unsolved mystery as her constant companion." Once somebody told her on the phone to identify a corpse in the morgue: "the deceased had been pushed from a sixth-floor window and had died on contact with the pavement." Françoise could recognize the corpse; it was her husband's (126). A man later told her the story of the past fifteen years: that Duclos worked for The General Directorate for External Security (DGSE); that he was "under strict orders not to talk about" his work; that "all those years when she thought her husband was writing economic studies for the Ministry of Foreign Affairs, he was actually operating as a spy" for DGSE. Just after their daughter's birth, he was assigned to a mission that made him "a double agent:" seemingly working for the Soviets but actually serving as a spy for the French. Soviet spies ultimately discovered his real identity after two years and tried to kill him. Moreover, they "were keeping watch on Françoise and her daughter, the phone in the apartment was tapped, and if Duclos tried to call or visit, all three of them would have been murdered instantly." Accordingly, he chose to hide for the protection of his family while "stealing out to catch an occasional glimpse of his daughter, watching her grow up from afar,... observing his wife as her youthful looks slowly vanished" (127). The Soviets finally found Duclos and threw him out of his apartment window. Auster does not move beyond these words to comment on Françoise's problems as a woman who suffered the loss of her husband during the Cold War. However, Auster sympathizes with the young Françoise who loses her husband on their daughter's birthday and with the middle-aged Françoise whose old wound is refreshed after fifteen years. The question is how long a woman of war should suffer? Even if wars end, their memories prevail and those memories are cruel to those who lost their beloved ones.

The role of women in postwar years is patently displayed in Bicycle Thieves as well. This movie serves August's insistence on the importance of the role of women in supporting their husbands in postWWII Rome. The central woman's suffering represents the problems of the women of the time, especially housewives, who did their best to keep the family together. She is an image of what Sheridan calls the "Homefront woman:" she is "heroic in her own way, holding the family together under different conditions, sustaining their strength and courage despite the shortages of food and clothing, despite the blitz and the blackout" (1990, 37). The movie, as highlighted by August, thus illuminates the neverending contribution of women to the events surround warfare, on both social and economic grounds.

In La Grande Illusion, which recounts the story of French prisoners-of-war in German camps, two French officers succeed in escaping, ending up in a German woman's cottage. Although she lost her husband and brothers in the current conflict between the two nations, she helps the officers take refuge in her house, feeds them, and treats the injured one. In $M D$, Katya and August discuss the scene near the end of the movie when a sense of affection has been already developed between one of the men and the woman. Lieutenant Maréchal tells her that although he loves her he can only come back after the war. The men eat their meal with the woman and her daughter and then leave to cross the border into Switzerland, leaving the woman with her tears. As Auster reflects, "She has to go back into the house and... the dirty dishes... The men are gone now,... those dishes have been transformed into a sign of their 
Abshavi, Haj' jari

absence, the lonely suffering of women when men go off to war" (2008, 17-18). The woman's words on Maréchal's leaving show the depth of a woman of war's sorrow with no man to care for her: "I was alone so long. Waiting so long. If you knew how happy I was to have a man about the house" (La Grand Illusion 1937, 01:48:48-01:49:00). On the other hand, we feel the remorse of a French soldier incarcerated in a German camp who tells others that his wife back home is "sleeping around" with other men because he is at war (00:32:30-00:32:50). The contrast of two wives is striking enough here: a pious widow whose husband died in battle and an adulterous wife whose captured husband is still alive. We can argue that both of these women are victims of war: one suffering from her husband's death and the other revolting against her husband's absence. Moreover, recalling what Sheridan says about "Homefront woman" above, the men in this movie seem lost in the manly war setting. They have gone to the front line to defend their nation, their houses, and their women, while their women are running their houses as "Homefront" women. As Sheridan holds, the "Homefront woman" is

the embodiment of the national 'hearth' - what the rest of the country (i.e. men) are fighting for. She represents the community spirit of war, the notion that we all helped each other. She takes in evacuees and billeted soldiers. She knits blankets and serves tea to the troops. $(1990,37)$

These merits exactly match those of the German woman who lets the French Maréchal and Rosenthal into her house and is then ready to serve a passing German troop with tea and food in $L a$ Grand Illusion.

There is also the story of a widow, Noriko, in the movie Tokyo Story (1953), whose husband went missing in The Pacific War (1941-45). Eight years have passed since her husband's death but she has still remained loyal to him. When her in-laws visit Tokyo to give their son and daughter a visit, Noriko is more helpful to them than their own children. At the end of the movie, her father-in-law thanks her for everything and wants her to remarry and forget about his son. She replies that she is "quite selfish;" that “she isn't always thinking about the old man's son, that days go by and he doesn't even cross her mind once." After a little pause, however, "she confesses how lonely she is and how, when she can't sleep at night, she lies in bed wondering what will become of her." She continues, "My heart seems to be waiting for something... I'm selfish" (Auster 2008, 76-77). The old man, sympathizing with her, ensures her that she is honest and that he wants her "to be happy" (Tokyo Story 1953, 02:11:10). Noriko, as a pious widow, has actually sacrificed her youth for her late husband. And maybe she is right that she is selfish; she is selfish to have kept her marriage vow to a man who fought and died for their country.

Watching all these movies is a way to escape the effects of the videoed image of Titus's death regarding Katya's story. Katya even "blames herself for what happened, falsely linking herself to the chain of cause and effect that ultimately led to his murder" (Auster 2008, 168). She feels that it was her cold-heartedness that led Titus to go to Iraq: "He loved me, but I couldn't love him back.... I told him I didn't want to see him anymore, and so he went off and got himself killed. He died because of me" (163164). Grief-stricken, her only response to August's demand to prepare for a good change after nine months of homesickness is "I do not want anything to change" (164). Katya is suffering from some sort of trauma after the traumatic event of her boyfriend's death. In psychological terms, experiencing traumatic 


\section{Women of War in Paul Auster's Man in the Dark}

events at some point in our lives may "challenge our view of the world or ourselves." People's reactions to such events may last for a short time or a long time. Since trauma is "a very personal thing," what traumatizes one person can be of less or no significance to others. Such variation in peoples' reactions happens due to their "individual personality, beliefs, personal values, and previous experiences." So since a certain incident might be "unique" for a certain person, he/she might respond to that incident "with intense fear, helplessness, or horror." While for the military, the trauma mostly follows "direct combat duties, being in a dangerous war zone, or taking part in peacekeeping missions under difficult and stressful conditions," for civilians the trauma stems from "man-made events (such as physical or sexual assault, accidents, and witnessing the death or injury of others) or natural disasters (such as fires, earthquakes, floods, and ice storms)" (Veterans 2008, 1-2). Women as war victims back home belong to the second category and Katya has the same kind of trauma, especially when she blames herself for

Titus's death. It can be argued that Katya has been traumatized since Titus's death while she is constantly trying to forget him and his fate. The symptoms that prove her suffering from trauma are relevant in this regard: she "sleeps alone with her broken heart" (Auster 2008, 1); she is "as resistant to sleep as her immobilized grandfather" (12); and she "slumps back on the sofa with her feet stretched out on the coffee table, unmoving for hours on end, refusing to stir herself even to pick up the phone, showing little or no signs of life" except when August touches or holds her. August considers her present condition as "flattened-out existence" (15). Most traumatizing of all, Titus's murder scene constantly bothers her:

If I hadn't seen it, everything would be different. People go off to war, and sometimes they die. You get a telegram or a phone call,... that your son or your husband or your ex-boyfriend has been killed. But you don't see how it happened.... We saw how they murdered him,... I can't get rid of it. (166-167)

Katya has been watching movies "for the last couple of months" to try to forget Titus's death (Auster 2008, 13): "I need the images," she holds. "I need the distraction of watching other things" (166), since she is "not much into laughs" (168).

It is important to understand that when we experience some trauma, it keeps returning to our minds in order to have us make sense of it. A haunted mind as such might be always craving to soothe itself while the memories of the traumatic event constantly bother us. In other words, "intrusive thoughts and feelings about the trauma" keep coming and going "almost indefinitely unless the cycle is addressed in some way" (Veteran 2008, 6). Katya is in essence the victim of traumatization through media and what C. Caruth calls the "shock of sight" $(1996,42)$. The videoed image, just like a documentary about the horrors of war, is too terrifying for a woman whose man is the main role facing death. Shocked by the videoed scene, Katya is in fact one of those Americans, as Caruth reflects, "who are thus addressed not directly as participants in the events of the past but rather as spectators, as viewers of a fictional film. They are addressed, that is, in this fiction, through their indirect relation to their own history" (47). In other words, Katya finds herself indirectly related to Titus's death and the sight of his murder is too shocking for her to bear. 
Abshavi, Haj'jari

Regarding Auster's own interest and activities in script writing and directing in the film industry, it is tempting to argue that he is pointing to the horrors that the visual media create for people who are not physically involved in conflicts. Katya, not personally involved in the Iraq War, acts as if she is a war victim just because he is mentally haunted by the beheading video of his boyfriend. Her traumatic response to his death, witnessed through media, contributes to the power of media in simulating the "shock of sight," even worsened through visual effects, following a catastrophe. For Caruth, trauma "does not simply serve as record of the past but precisely registers the force of an experience that is not yet fully owned" $(1995,151)$. Katya's trauma as such repeatedly happens in so far as the videoed file/cassette/CD is available and can be replayed infinite times. Her trauma, in Caruth's words, is of a kind "that continually returns, in its exactness, at a later time" (153). Likewise, L. Badley (1996) argues that

Horror returns audiences to preliterate, somatic modes of knowing, and movies, television, and rock concerts most completely recreate the experience of the den or campfire. Sitting in the darkened theater, we re-encounter our earliest dreams. The visual and electronic media have been most directly responsible for the contemporary horror phenomenon. (2)

Badley then elaborates that, specifically in postmodern fiction where fact and fiction are lost through simulacrum and hyperreality, the subject's 'inner' reality coincides with the simulacrum, includes and even becomes fantasized bodies. Consciousness is changing. Where Freud hoped to reclaim the unconscious for the ego, postmodern/postliterate consciousness is usurped by information technology, and distinctions between self and world, body and mind, media culture and human reality, live and recorded, collapse. (11)

In this light, Katya is a subject of traumatization through (horror) media in a self-conscious manner. That is because of the "brutal simplicity" of horror films which makes them "intrinsically self-conscious" (Bradley 1996, 12). As P. Brophy explains: it "knows that you've seen it before; ... that you know what is about to happen; and it knows that you know it knows you know" (1986, 5). However, August, more conscious than her traumatized granddaughter, tries to have her understand that everything will change although cruelties continue to roam the world: "the weird world rolls on," he repeatedly says (Auster $2008,180)$

And finally, we can investigate the story of Owen's wife, Flora, who was pregnant at the time Owen went missing. In the first week after his return from his parallel world, she reveals that they will become parents soon. However, he sends her back to her mother in Argentina for her safety until he fulfills his mission, from which he never returns. This episode serves as a case in point about the sufferings of pregnant women who had to give birth to fatherless children after the war.

\subsection{Women as Combatants}

Female soldiers/officers, Sheridan (1990) argues, "seemed to have travelled the greatest distance from the traditional female role." In other words, female soldiers basically came from female "shop assistants, hairdressers, factory workers, domestic servants, office workers," and even schoolgirls. This 


\section{Women of War in Paul Auster's Man in the Dark}

striking transformation must have exposed them to "ambiguities in their sense of femininity:" taken away from the household and their responsibilities and duties; living with other women than their children, spouses or parents; eating food already cooked for them; learning skills formerly considered manly; exercising authority over men and women of lower ranks. Such new identities drew women closer to "violence and destruction" as part of "the military machine" (33). In MD, Auster does not elaborate on this aspect of women of war, neither in the main plot nor in the stories and movies that he recounts. However, Virginia Blain is covertly part of the military machine fighting for freedom, although her role as a double agent is more striking. The same account goes with Molly Wald, the waitress. Virginia and Molly also present us with two different portraits of female combatants: Virginia the caring one and Molly the uncaring one, or in other words, the militant woman with feminine passion and the one with manly aggression, regarding their treatment of Owen on his arrival to their world. While Virginia helps Owen in his mission just as a woman is helpful to her husband, Molly acts as an accomplice in pursuing and threatening Owen's life.

\subsection{Women as Peacemakers}

The widowed German woman in La Grande Illusion generously takes two French prisoners-of-war in, without betraying them to a passing German army. She even falls in love with one of them, suggesting that love knows no boundaries, even during wartime between enemies. The same woman could have been the subject of harassment if the two French lieutenants were members of a French troop attacking her village. Her words to one of them as leave their house contribute to the peacemaking role of women, if such a thing could happen, during wartime: "If you knew how happy I was to have a man about the house" (La Grande Illusion 1937, 01:48:48-01:49:00). In Goodman's words, "Ideologically, women were used to symbolize the nation as a loved woman in need of protection;" however, "in reality women have a long history of giving practical support to the military machine" (2002, 75). Goodman suggests that even women had the potency to turn into war makers or advocates since it was the nature of war that needed soldiers. For example, as Cockburn holds, as England was to face the Great War in 1914, "women of the Order of the White Feather accosted men of military age still out of uniform, giving them white feathers as a symbol of cowardice." Women are, however, considered as more "peaceable" than men and even "less supportive of war policies" $(2013,434)$. Auster's account of a real story reveals how women could fill the gaps of war cruelty with cross-country search for love during the German occupation of Norway in WWII:

[a Norwegian girl] had the misfortune to fall in love with a German soldier who died on the Russian front, and for a while she had to go to Germany to look after her mother-in-law-in a city under constant bombardment. (Auster and Siegumfeldt 2017, 121)

Ciocia suggests that the trope of "donna angelicata (angel-like woman)" is Auster's master trope in depicting his women. As such, Auster seems fascinated with the idea of a beaituful and caring woman "as a source of meaning and inspiration to her man" $(2011,98)$. However, the concept of donna angelicata is itself a label which idealizes the womankind and makes her the object of perfect satisfaction for men. 
Abshavi, Haj'jari

Auster's women, however, are more down-to-earth and their roles in life are basically defined in relation to men in a network of real relationships. "It's not always the case, not one hundred percent of the time," Auster says, "but for the most part women keep the world going" (Auster and Siegumfeldt 2017, 265).

\section{Conclusion}

In the context of war, the types of female roles that Auster presents us with in $M D$ include women of resistance, female war workers, women combatants, and women as peacemakers. These roles are local narratives that attack male hegemony to highlight and establish their deterministic roles during wartime and its aftermath. Since the main stories we read in $M D$ are about war, most of the women imagined by Auster also come to life in the context of war. By elaborating on war issues and the roles that men and women play meanwhile, Auster's general view about war is pro-feministic, away from any gender-biased argument. All the roles played by women during wartime are observable in $M D$ in a respectful manner Auster actually adores women's contribution to war through the stories he recounts. $M D$ thus presents us with a comprehensive list of roles that women undertook during different wars. Besides, Auster is not ignorant of the changes that women experienced through war and its aftermath, changes that did much to bestow them with new identities, although they suffered much in the process. 
Women of War in Paul Auster's Man in the Dark

$$
\begin{aligned}
& \text { نساء في الحروب فى (رجال فى الظلام) لبول أوستر } \\
& \text { موججان أبشافي } \\
& \text { قسم اللفة الإنجليزية وآدابها، جامعة بيام نور، إيران } \\
& \text { محمد جواد حجاري } \\
& \text { قسم اللفة الإنجليزية وآدابها، جامعة الرازي، كرمادئ حارياه، إيران }
\end{aligned}
$$

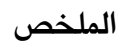

روايه للكاتب (اوستر) تضمنت العديد من قصص الحروب التي ساهمت في تقديم رسالة واضحة غَمًا اذا كان هناك عالم بلا حروب، وكيف سيبدو شكل هذا العاله. وأغلب قصص الحروب هذه تناولت الأدوار المختلفة التي لعبتها النساء في زمن الحروب، سواء كان الدور إيجابيا في المساهمة في دعم الحروب واستمرارها، او كان الدور الذي لعبته النساء من خلال التضحيات التي قدمنها كونهن زوجات داعمات لأزواجهن في المعارك، أو من خلال وقوعهن في الأسر، أو كونهن أرامل الجنود الذين سقطوا في المعارك، أو مستعبدات بعد وقوعهن في الأسر. كذلك تناول تضحياتهن من خلال تعرضهن للتغيير القسري للهوية والانتماء وإجبارهن على تقبل عادات وتقاليد اجتماعية وعرفية جديدة رغماً عنهن. هذه الصور عن النساء وأدوارهن في الحروب جعلت من رواية (رجال في الظلام) رواية عن النساء في زمن الحروب. إن الكاتب (اوستر) قدم نفسه كمؤيد لدور النساء في هذا المجال من منظور الحركة النسوية. هذه الروايه تبين لنا بعض أسباب اندلاع الحروب وأدوار النساء فيها وكيف

$$
\text { تمم تفييب مساهمات النساء بشكل متعمد وغير عادل عبر التاريخ. }
$$


Abshavi, Haj' jari

\section{References}

Alina-Oana, Pascu. 2014. Fictions That Kill in Man in the Dark. Ovidius University Annals: Economic Sciences Series 14: 212-17.

Auster, Paul. 1987. In the Country of Last Things. New York: Viking Press.

Auster, Paul. 2008. Man in the Dark. New York: Henry Holt and Company.

Auster, Paul, and Inge B. Siegumfeldt. 2017. A Life in Words: Conversations with Paul Auster. New York: Seven Stories Press.

Auster, Paul, and John M. Coetzee. 2014. Here and Now: Letters 2008-2011. London: Vintage Books.

Badley, Linda. 1996. Writing Horror and the Body: The Fiction of Stephen King, Clive Barker, and Anne Rice. London: Greenwood Press.

Briggs, Susan. 1975. Keep Smiling Through: The Home Front 1939-45. London: Weidenfeld \& Nicolson. Brophy, Philip. 1986. Horrality-the Textuality of Contemporary Horror Films. Screen 27 (JanuaryFebruary): 2-13.

Brown, Mark. 2007. Paul Auster. Manchester: Manchester University Press.

Caruth, Cathy, ed. 1995. Trauma: Explorations in Memory. Baltimore: The Johns Hopkins University Press.

Caruth, Cathy. 1996. Unclaimed Experience: Trauma, Narrative, and History. Baltimore: The Johns Hopkins University Press.

Ciocia, Stefania. 2011. "A Doomed Romance? The donna angelicata in Paul Auster's Fiction". In The invention of illusions: International perspectives on Paul Auster, ed. Stefania Ciocia and Jesús A. Gonzáles, 97-124. Cambridge: Cambridge Scholars Publishing.

Cockburn, Cynthia. 2013. War and Security, Women and Gender: An Overview of the Issues. Gender \& Development 21 (3): 433-52.

Costello, John. 1985. Love, Sex and War, Changing Values 1939-1945. London: Pan Books.

De Sica, Vittorio, dir. Bicycle Thieves. 1948. London: Arrow Academy, 2017. DVD.

Diehl, Jörg. 2007. Ich bin gekommen, um zu töten. Der Spiegel (July 2). https://www.spiegel.de/panorama/zeitgeschichte/ns-verbrecher-klaus-barbie-ich-bin-gekommen-umzu-toeten-a-489560.html. (accessed February 6, 2020).

Duncan, Raymond, Barbara Jancar-Webster, and Bob Switky. 2008. World Politics in the $21^{\text {st }}$ Century. Boston: Houghton Mifflin Vollege Div.

Giles, Judy. 1992. 'Playing Hard to Get': Working-Class Women, Sexuality and Respectability in Britain, 1918-40. Women's History Review 1 (2): 239-55.

Goodman, Philomena. 2002. Women, Sexuality and War. New York: Palgrave.

Hartley, Jenny. 1997. Millions Like Us: British Women's Fiction of the Second World War. Boston: Little, Brown and Company.

Higonnet, Margaret R., and Patrice Higonnet. 1987. "The Double Helix". In Behind the lines: Gender and two World Wars, ed. Margaret R. Higonnet, Jane Jenson, Sonya Michel, and Margaret C. Weitz, 3148. New Haven: Yale University Press. 
Klaus Barbie: Women testify of torture at his hands. 1987. The Philadelphia Inquierer (March 23). https://www.writing.upenn.edu/ afilreis/Holocaust/barbie.html. (accessed January 15, 2020).

Martin, Brendan. 2008. Paul Auster's Postmodernity. New York: Routledge.

Oliver, Kelly. 2007. Women as Weapons of War: Iraq, Sex, and the Media. New York: California University Press.

Ozu, Yasujirō, dir. Tokyo Story. 1953. London: BFI, 2010. DVD.

Plain, Gill. 1996. Women's Fiction of the Second World War: Gender, Power and Resistance. New York: Palgrave Macmillan.

Renoir, Jean, dir. La grande illusion. 1937. Santa Monica, CA: Lionsgate, 2012. Blue-ray.

Sheridan, Dorothy. 1990. Ambivalent Memories: Women and the 1939-45 War in Britain. Oral History 18 (1): $32-40$

Veterans Affairs Canada. 2008. Post-Traumatic Stress Disorder (PTSD) and War-Related Stress. Toronto: Veterans Affairs Canada. https://www.veterans.gc.ca/eng

Weatherford, Doris. 2010. American Women during World War II: An Encyclopedia. New York: Routledge.

Westerfield, Lillian Leigh. 2004. 'This anguish, like a kind of intimate song': Resistance in Women's Literature of World War II. New York: Rodopi.

Whaley, Leigh. 2006. "Marie-Madeleine Fourcade (1900-1985)". In Women and war: A historical encyclopedia from antiquity to the present, Vol. 1, ed. Bernard A. Cook, 191-92. Oxford: ABCCLIO. 